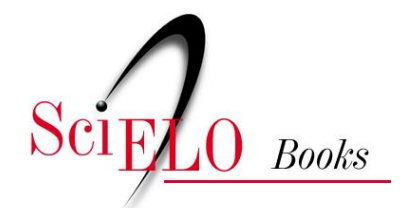

\title{
O congresso e a justiça no regímen federal
}

\author{
Rui Barbosa
}

\section{SciELO Books / SciELO Livros / SciELO Libros}

BARBOSA, R. O congresso e a Justiça no regímen federal. In: A questão social e política no Brasil [online]. Rio de Janeiro: Centro Edelstein de Pesquisa Social, 2010, pp. 54-77. ISBN 978-85-7982074-8. https://doi.org/10.7476/9788579820748.0002.

\section{() povoui}

This work is free of known copyright restrictions. http://creativecommons.org/publicdomain/mark/1.0/

Este trabalho está livre de restrições de direito de autor e/ou de direitos conexos conhecidas. http://creativecommons.org/publicdomain/mark/1.0/

Esta obra está libre de restricciones conocidas de derechos autorales. http://creativecommons.org/publicdomain/mark/1.0/ 


\title{
O CONGRESSO E A JUSTIÇA NO REGÍMEN FEDERAL
}

\author{
Em 21 de maio de 1895
}

Por sentença definitiva de ontem, comunicada para aqui telegraficamente e anunciada nas folhas inglesas desta manhã, o Supremo Tribunal Federal, em Washington, declarou inconstitucional em sua totalidade e, como tal, nula em todas as suas partes a lei do Congresso americano, que estabelecia o imposto sobre a renda. (Income Tax Act.)

Esta lição, que reveste caracteres especiais de solenidade, vem a talho de foice, para dar o último golpe no erro, indígena à nossa terra, dos que supõem à legislatura, sob o regime americano, adotado e acentuado, neste ponto, pela constituição de 24 de fevereiro, autoridade de legitimar, e subtrair assim à ação da justiça, aprovando-os, os atos in constitucionais do Poder Executivo.

Nos Estados Unidos, até os meninos de escola (desde as primeiras letras se ensinam ali estes rudimentos) não ignoram o asilo supremo reservado nos tribunais pela constituição a si mesma e aos direitos que ela protege contra as invasões quer do Executivo, quer do Congresso. Entre nós, porém, a azáfama, com que se propôs, e quis fazer-se transitar, o ano passado, por ambas as câmaras, a absolvição das inconstitucionalidades perpetradas pela ditadura, mostra a ingênua idéia, em que se acham os nossos constitucionalistas, de que as maiorias parlamentares podem, com o seu voto, impor veto à competência judiciária neste assunto.

O mais destemperado politician, o mais ordinário dos wirepullers de partido não se atreveria, na União Americana, a desconhecer assim aquela soberana prerrogativa da justiça, onde reside a chave mestra da organização republicana, a garantia das garantias contra o arbítrio das ditaduras e a cegueira das facções. Nós, porém, em matéria de idéias políticas, somos franceses, não americanos. Cada um dos nossos oráculos é uma miniatura de convencional, enfatuado no republicanismo fóssil de 1792, na presunção eminentemente revolucionária da supremacia absoluta do corpo legislativo entre os poderes republicanos. As sentenças proferidas pelo juízo seccional do Rio de Janeiro nas ações civis instauradas por mim a favor das vítimas dos decretos de abril de 1892, demonstram que a magistratura brasileira 
conta espíritos não contagiados ainda por essa ignorância da sua missão, cuja teoria jurídica me coube a honra de firmar no meu livro sobre Os Atos Inconstitucionais do Congresso e do Executivo. Mas a idéia espúria lavrou em tal extensão, que, não há muito, um periódico brasileiro de grande préstimo, publicado em Paris, atribuía à nossa magistratura o propósito de aguardar, como orientação para o seu procedimento, as deliberações legislativas esperadas a respeito da ditadura transata.

Muito a ponto vem, pois, o aresto americano de 20 do corrente. $\mathrm{Na}$ sua história, cheia de preciosos ensinamentos, se não para a ciência dos nossos jurisconsultos e a incidência dos nossos estadistas, ao menos para o comum dos cidadãos brasileiros, interessados em prover à defesa judicial dos seus direitos, palpita a questão de mais atualidade e alcance prático em nossa terra.

Seja qual for o reparo dos que hoje estranham a minha apologia da Inglaterra, a verdade é que, no Brasil, fui sempre um dos maiores preconizadores deste país, a que o mundo moderno deve a liberdade e Shakespeare:

This happy breed of men, this little world, This precious stone set in the silver sea, This blessed plot, this earth, this England.

As minhas expansões de entusiasmo pela magnificiência das instituições liberais aqui florescentes e mais ou menos copiadas daqui em todo o mundo contemporâneo, chegaram a merecer a cognominação de “ditirambos". Não sei o que venha fazer o delírio báquico em tais paragens. Mas, se a admiração pela Inglaterra tem o poder de inebriar as pessoas dadas aos vícios da sobriedade, direi que o meu gosto por esse licor data da minha entrada no jornalismo, na tribuna, nos corpos deliberantes. Se estivesse nas mãos de uma revolução converter a realeza pessoal dos Braganças na monarquia parlamentar da casa de Hannover, eu, em 15 de novembro, teria proposto a troca de Pedro II pela Rainha Vitória, a da Cadeia Velha pelo Paço de Westminster. Está claro que o Paço de Westminster exprime aqui o tipo da câmara popular e a Rainha Vitória o do soberano constitucional.

Privado, porém, de realizar esse prodígio, obrigado a escolher, para a república inevitável, a mais satisfatória das formas, há um regime, ao qual eu não daria jamais o meu voto, porque esse é o mais tirânico e o mais desastroso dos regimes conhecidos: a república presidencial com a onipotência do Congresso; o arbítrio do Poder Executivo, apoiado na irresponsabilidade das maiorias políticas; a situação autocrática, em que se coloca, neste sistema, o chefe do estado, se ao seu poder e ao dos partidos que ele encarna se não opuser a majestade inviolável da Constituição escrita, interpretada, em última alçada, por uma magistratura independente.

Quando afirmo que, na Inglaterra, a liberdade é mais ampla, mais estável, mais defendida que nos Estados Unidos, não faço mais do que enunciar uma proposição trivial, nos próprios Estados Unidos, entre os que conhecem as duas nações. Foi um dos homens que representam a mais alta expressão do gênio americano quem disse: "A Inglaterra é a melhor das nações atuais". E acrescentou: "Na estabilidade da Inglaterra jaz a segurança do mundo moderno. Se a raça inglesa fosse tão mudável, como a francesa, em que se poderia confiar? Mas a Inglaterra não faltará à liberdade". E é outro americano, dentro os seus maiores escritores, o grande historiador da Holanda, Lothrop Motley, quem não hesita em reconhecer essa superioridade:

"Tenho imensamente mais respeito pelo governo de Inglaterra do que pelo nosso: não posso deixar de considerá-lo como regido por princípios de ação muito mais altos, por motivos muito mais elevados."

Ainda agora uma embaixatriz do quarto estado naquele país, uma jornalista, mandada aqui especialmente por certa folha americana para apurar o confronto, chega às mesmas conclusões que eu. Acaba ela de publicar a sua confissão em uma revista inglesa. A princípio o seu ódio a este país lhe inspiraria duzentas páginas de diatribe contra a Grã Bretanha. Mas, afinal, a verdade lhe subjugou o orgulho yankee. As suas Impressions of John Bull foram arremessadas ao fogo. "Curei-me da minha anglofobia", diz ela, "simplesmente com o viver aqui, e deixar a moléstia entregue ao seu curso natural". As suas "Impressões e Comparações", estampadas no Nineteenth Century do mês passado, são um auto de fé das suas ilusões americanas.

"Um dos enganos, de que o meu espírito se desencantou com a residência em Inglaterra, é a idéia, em que eu vivia, como meus conterrâneos, de que a América é a região da liberdade. À minha primeira 
visita a Hyde Park logo se produziu em mim a persuasão de que a liberdade é muito maior na Inglaterra do que na América."

Ante a independência, com que naquele comum logradoiro dos meetings populares, se debatem, sob a proteção da polícia, as opiniões mais violentas, a jornalista americana, que seguramente não é nenhuma sacerdotisa de ditirambos, não hesita em magoar assim o melindre norteamericano:

"Eu nunca vira tamanha manifestação de liberdade. Se tal se tentasse em Central Park, na cidade de Nova Iorque, a maior parte dos oradores e muitos dos ouvintes seriam sacudidos à cadeia. Agora saber se essa liberdade inglesa bem faz, ou mal faz às classes superiores, ou inferiores, é questão diversa. Mas ninguém, que haja habitado as duas capitais, poderá negar a existência de mais liberdade em Londres do que em Nova Iorque."

$\mathrm{Na}$ Inglaterra esse respeito cultual da liberdade, política e civil, tem origem, não só no inimitável mecanismo de freios e contrapesos, que caracteriza a sua constituição, como na lenta elaboração que a veio desenvolvendo gradualmente em dois séculos de contínua legalidade, e, em grande parte, no espírito singularmente constitucional dos seus últimos soberanos. Essa docilidade perfeita da família reinante na Inglaterra à prá tica sincera do governo parlamentar, cuja cavilação impopularizou e per deu a monarquia no Brasil, culminou na Rainha atual, de quem, num livro publicado neste momento, escreve o mais recente dos seus biógrafos:

"Não se exagerará, dizendo que, pela sua sagacidade e devoção persistente ao dever, ela criou o moderno constitucionalismo, e, mais do que outra qualquer pessoa, individualmente considerada, fez da Inglaterra e da monarquia inglesa o que uma e outra são hoje em dia."

Não há, por outro lado, país livre, onde a sociedade e a política desenvolvam agora influências mais dissolventes do que nos Estados Unidos.

A democracia americana sofre de males tão crônicos que um dos seus mais eminentes historiadores em um ensaio intitulado A Perversão Política dos Patriarcas da República, dado a lume este mês, se propõe a demonstrar, e parece-me havê-lo conseguido sem dificuldade, que, "em todas as tretas e fraudes, cujo concurso produziu o pior gênero de praxes políticas, os fundadores do nosso governo federal e dos governos dos nossos estados" (é um americano quem fala) "foram sempre nossos iguais, e muitas vezes nossos mestres".

Socialmente não há nação mais agitada pelo espírito de ódio e revolta. A opressão e o ostracismo do negro, o desenvolvimento das distinções de classes, a organização do trabalho e da riqueza em corpos arregimentados um contra o outro, a medonha expansão do socialismo, do anarquismo, do paredismo (relevem-me a palavra) são outros tantos fenômenos, que ameaçam gravemente a vida nacional. Deles traçava o mais sombrio quadro, há poucos meses, distinto economista, com um agregado formidável de fatos e uma justeza de raciocínio irresistível.

Não quero falar na depressão econômica e financeira, ante a qual empalidecem as desgraças de 1857 e as perturbações que varreram o país entre 1870 e 1875: quebras de centenas de bancos; liquidação de cidades inteiras; fábricas fechadas; baixa profunda nos depósitos bancários; queda nos títulos nacionais; redução no preço dos produtos agrícolas e no valor da terra; depreciação da moeda; falências de companhias ferroviárias na importância de centenas de milhões; subtração de \$80,000,000 ouro à circulação do país no espaço de doze meses.

Essa torrente de males, essa conspiração de calamidades, suficientes por si sós para levar à ruína uma grande nação, não passam de incômodos ligeiros, se a comparamos ao abalo orgânico determinado ali pelas questões sociais, com os instintos ateados por elas no ânimo de uma população, onde as qualidades sãs da primitiva estirpe saxônia lutam a custo contra os vestígios corrosivos do cativeiro e as paixões fero zes de tantos elementos adventícios, dificilmente assimiláveis, que fervem entre aquele povo, na imigração eslava, na imigração irlandesa, na imigração sul-italiana. A lei de Lynch, cujos episódios emparelham com as mais hediondas cenas da selvageria das tribos exterminadas na América pelo europeu, supliciou e matou, de 1886 a 1894, em desafio à magistratura, à policia, às milícias e à tropa, não menos de 1.962 homens, segundo uma estatística segura da Chicago Tribune. Há, na história dessa instituição infernal, que baniu da humanidade o homem de cor, requintes de atrocidade fabulosos: criaturas humanas assadas em vida; mulheres aplicando a chama de archotes à carne palpitante de negros tortura dos, em presença de turbas rugidoras de cidadãos; um ajuntamento de dez mil homens no Texas, cauterizando a 
ferro em brasa um mestiço in defeso para o queimar depois ainda vivo; três outros desses infelizes sucessivamente enforcados, por não se prestarem a delatar o esconderijo de um irmão. E isso em retaliação contra as faltas mais veniais; e isso nas praças de cidades, assoberbadas pela onda cruel; e isso não só nos estados meridionais, onde sete milhões de negros se defrontam com quinze milhões de brancos, como em toda a parte, Norte e Sul, Leste e Oeste.

Dessa escola bárbara não podiam deixar de resultar devastações tremendas no caráter nacional. A desumanidade adquirida no extermínio do negro devia forçosamente voltar-se contra a população branca, apenas esta se retalhasse em campos hostis. É o que sucedeu, uma vez aberta a guerra social entre ricos e pobres, em um país onde cento e dezenove nababos de Nova Iorque concentram nas mãos uma renda anual de mais de $\$ 97,000,000$, e onde "o Senado se converteu em uma espécie de corporação impenetrável de milionários e monopolistas, a cujo lado a Câmara dos Lordes, em Inglaterra, é uma tênue sombra de poder pessoal e riqueza particular".

Foi a lei de Lynch, horrenda expressão da anarquia cimentada em sangue nos costumes populares, mais do que a defeituosa organização das instituições americanas, mais do que as aluviões de escória européia absorvidas constantemente nos reservatórios onde se elabora aquela sociedade em formação, que educou essas massas, onde os Coxeys e os Debbs vão buscar as suas hordas. O operário americano é mais bem retribuído que o inglês; os seus salários deixam-lhe margem à economia; as leis do país, além de lhe assegurarem a mais completa liberdade de ação coletiva, dão-lhe, em muitos estados, a preponderância eleitoral. Contudo, a não ser a Sicília, onde a situação do obreiro é desesperadora, não há país, onde o trabalhador seja inflamável e violento como nos Estados Unidos. O frenesi da guerra operária, ali, assombra a Europa. As paredes americanas começam armadas, degeneram instantaneamente em batalhas, e manchamse logo em homicídios. Na Revista Contemporânea de julho do ano passado, um publicista muito conhecido agrupou as peripécias características da luta do trabalho contra a fortuna em uma crônica tal de fatos, que, conquanto abranjam apenas o decurso de alguns meses, nada se lhes compara na história das violências socialistas neste continente, ainda quando reuníssemos em um só corpo todos os incidentes congêneres registrados na Europa, aquém do Vístula por espaço de muitos anos.

Em face dessa pintura, fiel em todos os seus pormenores, um dos órgãos mais conceituados e judiciosos da imprensa européia disse, estupefato:

"Os assassínios sucedem aos assassínios, os atentados aos atentados, até que o leitor atônito pergunta se tem diante dos olhos a realidade na maior das repúblicas, ou em alguma região rudimentarmente civilizada, na Coréia, ou em Uganda.

"E, o que é ainda pior, essa fúria, que inflama os ânimos abra sados nas doutrinas mais subversivas, insensivelmente, como consequência normal, a que não se opõe reparo, passa dos desvairados às autoridades associando-as ao mau exemplo dos processos brutais.

"Os cidadãos prepostos à custódia da ordem ferem, e matam, com a mesma presteza dos que a atacam, usando a polícia de revólveres e outras armas de morte, ainda entre populações urbanas, com uma facilidade que, na Europa, levantaria insurreições.

"Juntai a isso a fraqueza do poder federal sobre as desordens locais, as acusações insistentes contra a influência dos sindicatos na vida legislativa, a instabilidade entretida na esfera do Executivo pela deslocação periódica de seu pessoal, a mediocrização crescente dos cargos públicos, entregues aos empreiteiros políticos pela eliminação das capacidades independentes, o charivari das extravagâncias inovadoras nos Congressos dos estados, o descrédito da justiça provincial, efeito da influência arruinadora do princípio eletivo introduzido na organização da sua magistratura, em regeneração da qual já se começa a advogar a vitaliciedade universal dessas funções, reunida ao seu provimento pelo governo; e teremos uma situação de infinitos perigos. Entre eles apenas se levanta uma rocha, a cujo pé vêm morrer as tempestades: a rigidez desse direito constitucional, que a corte suprema, auxiliada pelos juizes federais, interpreta e fixa."

Por isso é que, estudando essa autoridade, Bowyer, um dos clássicos da jurisprudência inglesa, dizia, já há quarenta e cinco anos, nas suas lições 
em Middle Temple: "Pode-se afirmar com segurança que, se não fora essa jurisdição extraordinária, a federação americana não duraria muito”.

A inalterabilidade da constituição, observa um contemporâneo, é a grande salvaguarda dos Estados Unidos. De encontro a ela vêm quebrar-se em vão todas essas leis más e insensatas, que triunfam nas legislaturas dos estados. É pela sua manifesta inconstitucionalidade que muitos desses bills se transformam em lei sem opugnação. "Para que perder tempo em combater essa medida?" alegam os adversários de idéias perniciosas. "Passe". O Supremo Tribunal declará-la contrária à constituição; e será como se tal projeto nunca houvera existido."

No caso em questão, porém, não foi contra atos legislativos dos estados, mas contra uma lei da União, que a suprema corte federal exerceu a sua autoridade oracular de hermeneuta irrecorrível da carta americana.

II Não há, entretanto, seis meses que um dos publicistas norteamericanos de mais alta reputação, em um profundo estudo publicado na revista política de Columbia College, defendendo a income tax atual contra as arguições de injustiça, socialismo, inconstitucionalidade, e reunindo os precedentes judiciários, que pareciam justificá-la, concluía, dizendo: "Não há motivo de supor que esta jurisprudência venha a ser reformada".

Não é, com efeito, a primeira vez que ali se ensaia o imposto sobre a renda. Vários tentamens desse gênero se registram, assim na legislação dos estados, como na da União. No Massachusetts, por exemplo, em virtude de uma regra tributária, depois ampliada às outras colônias da Nova Inglaterra, se estatuiu desde 1646, a taxação de todos os indivíduos for their returns and incomings, disposição, que, reiterada e desenvolvida em 1706, em 1738, em 1777, penetrou e consolidou-se, afinal, na constituição do estado. Além desse, entretanto, só no de Virgínia, onde foi introduzido em 1849 , mais no da Nova Carolina, onde se adotou no mesmo ano, subsiste essa contribuição, mas com mui tênue resultado. No Alabama, admitida em 1843, foi extinta em 1884.

O governo da União mais de uma vez cogitara nesse recurso, bem que apenas como expediente temporário. Durante a guerra de $1812 \mathrm{com}$ a Grã Bretanha o ministro do Tesouro, Dallas, alvitrou um plano geral de income tax, a que a celebração da paz, semanas depois, não deu tempo de passar de proposta a ato legislativo. A guerra civil suscitou de novo esse pensamento, levado a efeito em 1862 mediante um income duty on all annual gains, profits or income.

Essa providência que veio a cair em impopularidade com a cessação das urgências financeiras do país, vigorou durante dez anos, produzindo ao todo uma receita de $\$ 346,911,760$.

Sob o domínio dessa lei houve quem averbasse de inconstitucional a income tax, como imposto direto, cuja fixação não se conformara à cláusula prescrita pela lei fundamental para esse gênero de contribuições. Mas a Corte Suprema, estribando-se em considerações análogas às de outra sentença sua, proferida nos primeiros anos da república, estatuiu que esse imposto não era direto na acepção constitucional. Nas considerações que fundamentaram o primeiro dos dois arestos (Hylton vs. United States), se alegava que as únicas contribuições diretas, contempladas na intenção do legislador constituinte, eram o imposto de capitação (poll tax) e a taxa geral sobre a propriedade.

Com as reformas financeiras enterreiradas, em dezembro de 1893 , pelo bill Wilson, que modificou o regime protecionista das tarifas americanas, coincidiu o projeto concernente às rendas internas da federação, no qual reaparecia, sob forma nova, a income tax. A medida, formula da pelos democratas, com aplausos calorosos dos populistas, e submetida à committee of ways and means em janeiro de 1894, foi vigorosamente combatida, não só pelos republicanos, senão também pelos deputados democráticos dos estados orientais, e passou na Câmara dos Representantes, graças aos sufrágios do Sul e Oeste, por 204 contra 140 votos, incorporando-se ao tariff bill. Contra a opinião do Presidente Cleveland na mensagem de 4 de dezembro, a nova income tax não gravava unicamente as associações: seu ônus direto estendia-se às rendas individuais.

Esse encargo, que devia atuar por cinco anos, contados de $1^{\circ}$ de janeiro de 1895 , consistia em um tributo de $2 \%$ sobre toda a porção de renda pessoal, ou coletiva, que excedesse de $\$ 4.000$ anuais, recaindo sobre todos os habitantes dos Estados Unidos, nacionais, ou estrangeiros, bem como os residentes no exterior, que tivessem bens, ou negócios, no país.

Esse meio de receita fora sugerido ao legislador pelas sérias dificuldades, entre as quais se via o erário federal, com a grave 
desorganização, em que tinham vindo a parar as suas finanças. Os saldos consideráveis de 1890 haviam decaído progressivamente, de ano em ano, até se nulificarem quase de todo em 1893, convertendo-se, em 1894, no espantoso déficit de 69 milhões de dólares, ou 14 milhões esterlinos: cerca de 350.000 contos ao câmbio brasileiro atual. Com o decrescimento da receita, que, no exercício atrasado, foi a menor das arrecadadas desde 1878, e a elevação das pensões, cuja verba montava em 141 milhões de dólares, não era de admirar esse resultado.

Eliminar, pois, a mais importante das contribuições instituí das para acudir a tamanho desequilíbrio era abrir, em hora de apuros, um respeitável desfalque no orçamento federal. Todavia, os que tinham articulado, no Congresso, a inconstitucionalidade do projeto, e a opinião, que, fora da Câmara, os apoiava com ardor, não trepidaram em levar o assunto à presença da justiça, que, por sua parte, não hesitou em condenar o novo tributo, não obstante os profundos interesses do governo federal na manutenção da lei votada e a violenta corrente popular, agitada pelas influências socialistas, que a amparava.

A suprema corte federal empregou uma semana em ouvir, sobre o assunto, a argumentação dos mais hábeis jurisconsultos do foro americano, como o ex-Senador Edmunds, Mr. Seward, Mr. Joseph Choate, o último dos quais proferiu uma oração qualificada como o maior surto de eloquência, de que há memória naquele tribunal durante estes cinquenta anos.

A impugnação da lei bifurcava-se em um dilema: ou a contribuição arguida de ilegal entra na classe dos impostos diretos; ou deve inscrever-se no capítulo dos "duties, imports and excises", que compreende, com os direitos de consumo e as taxas de importação, os impostos sobre indústrias e profissões.

Se era uma contribuição direta, o preceito do art. $1^{\circ}$, seç. 9 , cláusula $4^{\mathrm{a}}$ da Constituição federal exige que se distribuísse pelos estados proporcionalmente à população: "No capitation or other direct tax shall be laid unless in proportion to the census". Ora, fixada, como estava a income tax pela lei de 1894, dezenove vigésimas partes da arrecadação orçada recaíam sobre esta dos que abrangem apenas $25 \%$ da população total; sendo que quatro quintos do fardo pesariam unicamente sobre o de Nova Iorque.
Se não era uma contribuição direta, como o tribunal tinha entendido na questão Springer, havia forçosamente de averbar-se sob a rubricados "duties imports and excises". Mas, segundo a cláusula $1^{\mathrm{a}}$ da seção $8^{\mathrm{a}}{ }_{2}$ na constituição americana, os impostos englobados sob esta tríplice designação têm de ser uniformes em todo o país: "All duties, imports and excises shall be uniform throughout the United States". E a income tax ora estabelecida violava essa regra, isentando certas pessoas, certas espécies de propriedades, e favorecendo parcialmente outras. Companhias de seguro mútuo, por exemplo, com um capital coletivo de $£ 250.000 .000$, escapavam ao ônus, que ia cair sobre modestos negociantes, cuja capital não passava de $£ 14.000$.

A defesa da lei, de cuja habilidade e proficiência já tínhamos versão notável no artigo recentemente publicado por Mr. Seligman em uma revista americana, foi deduzido no tribunal pelo Attorney General (ministro da Justiça), auxiliado por Mr. Carter. Na opinião de Mr. Olney e seu colega, a income tax não é um imposto direto. Segundo o seu raciocínio, a renda territorial, por exemplo, uma vez embolsada pelo proprietário, perde a sua individualidade, confundindo-se com outros quaisquer valores pecuniários re unidos na algibeira do contribuinte. Taxar a terra, sem observância da proporcionalidade exigida pela constituição, seria, confessavam eles, inconstitucional. Não havia, porém, inconstitucionalidade, uma vez que o encargo in cidia, não sobre a terra, e sim sobre o seu rendimento.

Se, por outro lado, a taxa increpada entrava na classe das excises, o argumento, retrucavam os seus advogados oficiais, não procedia; visto como, segundo eles, a palavra "uniformidade", no texto de constituição federal, alude à identidade territorial dos tribunais em toda a superfície da União, não à "igualdade" da sua incidência entre os contribuintes.

Os órgãos do ministério publico, se me é lícito aplicar àquele país esta denominação peculiar à fraseologia de outros, abertamente reconheciam que a lei era desigual. Mas a igualdade, em tal ordem de coisas, era, a seu ver, impraticável.

"O Congresso", dizia o Attorney General, "fixou o mínimo da renda tributável no limite de 4.000 dólares. Essa, pode-se dizer, é a raia, que separa da seção superior a seção inferior da classe média, financial mente 
falando, nas grandes cidades, e a que, no campo, traça a divisória entre a classe média e a rica."

E eis aí o primeiro funcionário da administração da justiça, numa república, onde se deveria presumir que todos os homens são iguais perante a lei, confessando francamente que esta os distinguia em classes, aquinhoando-os diferentemente segundo elas.

O impulso decisivo em favor dessa reforma veio indubitavel mente das camadas sociais que lucravam com a imunidade assegurada aos rendimentos menores de 4.000 dólares. Quem o reconhece é o próprio Seligman, o douto professor, o escritor americano que mais afincadamente se tem batido pela income tax. Mas, acrescenta ele caracteristicamente, cumpre não esquecer que "houve séria provocação a isso". Como o gravame das tarifas protecionistas onerou por muitos anos os estados meridionais, a benefício dos pensionistas do Norte, natural era que, havendo oportunidade, se invertessem as posições. Temos, assim, pois, uma iniquidade em revindita de outra: uma lei justificada pelo seu caráter retaliativo. E a isso chama o ilustre publicista "um ato de justiça reparatória, a piece of retributive justice". Ele não contesta que os estados agrícolas do Sul e Oeste se locupletariam em dano dos centros fabris do Leste e do Norte. Mas o antagonismo geográfico, explica Mr. Seligman, como se a explicação não deslocasse apenas a face odiosa da injustiça, é meramente acidental. O movimento não vem do Ocidente e do Sul contra o Norte e o Oriente, mas da lavoira contra a indústria e o capital, localizados os dois últimos numa, e aquela noutra zona do território americano.

Por confissão dos seus melhores apologistas, o imposto sobre a renda era, já se vê, a desigualdade feita lei, o país retalhado juridicamente em classes hostis uma à outra, a luta a golpes de maioria entre os diferentes elementos da nação.

Prosseguindo na exculpação da medida financeira, observava o Attorney General:

"Reunindo em classe especial as corporações mercantis, e taxandolhes a renda em proporção superior à que onera os lucros individuais, esta lei dobra-se apenas a fatos e condições sociais, que fora estultície desconhecer."

\section{E acrescentava:}

"É de comezinha notoriedade que as companhias são agências tão prósperas na exploração do comércio e acumulação da riqueza, que uma vasta seção da comunidade as encara com intenso desagrado, como invenções artificiosas e malignamente engendradas, para opulentar os opulentos, empobrecendo os pobres."

Era deixar ver claramente que o Congresso obrara sob o clamor de paixões populares, adversas aos princípios cuja subestrutura aguenta a organização atual da sociedade. Não será isso o princípio desse "perigo", a que aludia Vítor Hugo em um dos seus lúcidos intervalos de pensador? O tribuno, que tanto lisonjeou a demagogia, teve uma vez, acerca da inanidade de tais reivindicações, algumas dessas palavras, cujo sulco não se apaga, quando mostrou que não é a indigência, mas a inveja, o que inspira esses movimentos, que não é contra os ricos, mas contra a riqueza, que os pobres levantam a mão, sem advertirem que, extinta a riqueza, "nada mais haverá para ninguém".

Nunca, a meu ver, os maus sinais se acentuaram de modo mais expressivo no horizonte contemporâneo; porque, dada a majestade da Corte Suprema nos Estados Unidos e os hábitos de veneração religiosa, que, naquele país, a sagram, ninguém imaginaria que o órgão dos direitos do estado perante ela ousasse insinuar-lhe a imprudência de uma decisão contrária às simpatias da multidão, falando à justiça em nome de considerações interessadas, e agitando transparentemente aos olhos da magistratura ameaças à sua existência. Tal foi, entretanto, a linguagem de Mr. Carter, cujo discurso findou nesta peroração memorável:

"Não vá o povo, quando na hora do seu triunfo encontre obstruído o caminho por uma sentença judicial, não vá ele, se preciso for, caminhar até à satisfação dos seus intuitos, passando por sobre a constituição e os tribunais."

Essa maneira insólita de envolver a justiça na onda política, essa atitude extraordinária do governo diante de um tribunal, acendeu na palavra de Mr. Choate a eloquência dos grandes dias da tribuna forense. A indignação, temperada pelo respeito, acordou no jurista o ora dor: e a resposta dardejou em alguns rasgos fulgurantes dessas vibrações da justiça, a que as sociedades mais materializadas não são insensíveis. "Nunca me 
poderia ocorrer", exclamou ele, "o arbítrio de abrir, ou encerrar um arrazoado perante esse tribunal, exorando-o a denegar a proteção devida aos que buscam o abrigo desta grande arca da aliança, sob a insinuação do perigo de arriscar-se a ser varrido pela cólera popular. É a primeira vez que ouço articular essa consideração ante este ou outro qualquer tribunal de justiça; e fio que seja a última."

Depois, examinados e refutados os argumentos principais da defesa, disse o eminente advogado, o mais alto vulto do foro de Nova Iorque: "Tenho passado hoje por algumas surpresas. Até agora supunha eu existir uma constituição nos Estados Unidos, e cuidava que a missão do braço executivo era sustentar essa constituição. Parecia-me que este tribunal fora instituído, para manter a constituição contra os atos do Congresso, que a transgredissem. É absolutamente novidade, para mim, que o Congresso seja o juiz exclusivo da extensão dos poderes, em que a constituição o encerra, como é novidade, aos meus ouvi dos, que já não tenha existência este princípio fundamental à constituição: a igualdade de todos os indivíduos perante a lei."

E adiante: "São comunistas e socialistas os argumentos, em cujo nome se propugna este imposto. Se estas isenções subsistirem, a marcha comunista prosseguirá, e, daqui a cinco anos, se decretará uma taxa de 20 por cento sobre as rendas maiores de 20.000 dólares. Imaginava eu que o objeto capital de todo governo civilizado fosse a preservação do direito de propriedade individual. Isto é o que Mr. Webster dizia em Plymouth Rock, no ano de 1820; e eu acreditava que nisto se achassem de acordo todos os homens educados e todos os homens civilizados. Com as doutrinas expendidas, porém, aqui esta manhã, até esse grande princípio fundamental foi entregue aos ventos. Washington e Franklin tinham a fé desse princípio. Pudessem eles prever que, dentro em pouco, ante a Suprema Corte dos Estados Unidos, se sustentaria que a constituição, obra do seu concurso, autorizava uma coligação de estados a penetrar, por meio de uma lei, no cofre dos cidadãos de outros estados, apoderando-se de todas as fortunas maiores de 100.000 dólares para uma distribuição geral pelo país; adivinhas sem no eles, e teriam corrido a riscar as suas firmas de um instrumento susceptível de interpretação tal."

Cinjo-me a transcrever esses lances, característico do espírito de oposição constitucional ao Income Tax Act, evitando a parte técnica da argumentação, deduzida especialmente nos discursos de Mr. Edmunds e Mr. Clarence, por ser impossível, atenta a sua natureza, reproduzi-la em excertos; além de que o comum dos leitores, alheios a estudos jurídicos, não lhe sofreria a aridez. Basta dizer que o Juiz Field, the Father of the Court, o patriarca do tribunal, qualificou-a como a mais hábil, que jamais ouvira

Encerrados os debates, que tinham começado no princípio de março, a Corte Suprema, após um mês de deliberação, proferiu a sua primeira sentença aos 8 de abril. Nessa data o juiz Fuller, em presença de grande auditório, onde sobressaía o mais numeroso concurso de juristas e altos funcionários, leu a decisão do tribunal. Segundo ela, o imposto sobre a propriedade imóvel, portanto um imposto direto e, como tal, nos termos em que a lei de 1894 o prescrevia, atentatório da constituição; declarando-se também incursa na mesma nulidade a taxa sobre títulos de renda municipais e estaduais.

No primeiro ponto o tribunal se manifestava por seis votos contra dois; no segundo, por cinco contra três. Quanto às outras disposições da lei, que poderíamos reunir sobre a inscrição geral de taxas sobre dividendos e vencimentos, os sufrágios se dividiam meio pelo meio.

O empate, era, porém, meramente material; porquanto os nomes inscritos contra a lei representavam um conjunto de autoridade moral mui superior à dos que se pronunciaram pela legalidade: o juiz Field, o decano da casa, membro do tribunal, desde 1864, irmão do finado internacionalista David Dudley Field, autor do célebre projeto de codificação do direito das gentes, e de Cyrus Field, "cujo nome é uma potência entre todas as classe"; o Juiz Fuller, conhecido pela sua competência profissional e absoluta neutralidade política; o Juiz Brewer, discípulo de David Dudley Field, com trinta anos de experiência na magistratura; o Juiz Carey, enfim, antigo membro da Suprema Corte de Mas sachusetts, de onde foi transferido, com brilhante fé de ofício, para a Suprema Corte Federal.

Entretanto, apesar de não abranger a lei toda, o aresto não era menos importante na sua significação e no seu alcance: porque nas duas seções anuladas se encerravam as mais graves disposições daquele ato legislativo, as defendidas mais energicamente pelo People's Party e pelas organizações rurais do Sul e Oeste. Essas cláusulas eram as que feriam especialmente as grandes propriedades e os grandes capitais acumulados nas zonas fabris, nas 
vastas indústrias do Norte e Leste. De modo que, na frase do correspondente do Times, essa decisão representava "em substância uma vitória em toda a linha para os antagonistas da income tax".

Ao mesmo tempo, ela envolvia, para o tesouro federal, um prejuízo de 10.000,000 de dólares, ou 50.000 contos da nossa moeda, anualmente, perfazendo, no quinquênio da lei, o total de 50 milhões de dólares, ou 250 mil contos em dinheiro nosso.

III No Brasil, onde aliás o direito constitucional é o mesmo, seria para levantar uma tempestade essa audácia de cinco juízes, sem exército, sem partido, sem meios materiais de ação, firmados unicamente na autoridade abstrata do seu cargo, na prerrogativa jurídica da sua dignidade, arrostando com uma simples sentença os grandes interesses do erário nacional, a maioria das duas Câmaras do Congresso, as paixões socialistas das classes laboriosas contra as classes opulentas, as retaliações locais do Norte contra o Sul, do Oriente contra o Ocidente, da multidão inumerável da pequena lavoura contra a diminuta minoria da grande indústria, a vontade impetuosa, em suma, de "uma massa de eleitores tão esmagadora" que, na representação federal, "leaders republicanos", adversários do projeto, preferiram catar silêncio a correr o risco de combater idéia tão popular".

Quereis ver, porém, como se passaram as coisas nos Estados Unidos? No dia imediato o correspondente do Times em Filadélfia tele grafava para aqui:

"Acredita-se geralmente que a lei, emasculada assim, terá de ser em breve revogada pelo Congresso. A administração reputa conveniente a abrogação total da lei. O Attorney General declara que aceita a decisão do Tribunal, e não pedirá reconsideração do feito."

A submissão do Congresso pode-se considerar, pois, como previamente consumada na submissão instantânea do governo e no respeito com que o assenso geral do país acolheu a decisão do tribunal. Ninguém cogitou em resistir. Ninguém teve uma palavra de despeito. "É corrente", anuncia editorialmente o Times, "que Mr. Cleveland e o seu gabinete estão deliberados a aconselhar a revogação completa da lei”.
Mutilada nas suas cláusulas capitais, ela ficara virtualmente inabilitada, para operar com eficácia nas outras disposições, enfraqueci das também pelo empate entre os magistrados, cuja divisão igual de votos abria a porta a discussões e subterfúgios incalculáveis. As autoridades do tesouro viram para logo o caminho de resistências e litígios intermináveis, em que ia tropeçar a cada passo a arrecadação do novo imposto. Sugeriu-se, pois, se não conviria uma reunião extraordinária do Congresso, a fim de prover ao desfalque inesperado, que se ia produzir na receita. $\mathrm{O}$ governo, porém, não considerou de imediata necessidade o expediente. Então vá rias, dentre as mais proeminentes folhas americanas, em diferentes cidades, começaram a exortar o presidente da República a examinar se não cumpriria suspender a lei manca e embaraçosa, até que o corpo legislativo tivesse ocasião de substituí-la.

Os interessados, porém, que, naquele país, não estão habituados a abrir mão dos seus direitos, ou a confiá-los aos cuidados paternais do governo, assentaram em provocar o tribunal a uma solução definitiva do ponto deixado em litígio pela primeira sentença. E o tribunal, solicitado por um recurso de acionistas de bancos e vias férreas contra o ônus lançado sobre os seus dividendos, assentiu em reconsiderar a matéria em questão.

Ventilado o assunto na audiência de 6 do corrente, a Corte Suprema, dois dias depois, adiou a decisão para a assentada de 20, em que o Chief Justice Fuller procedeu à leitura da sentença, cujos termos rezam:

"O tribunal persiste na opinião, já expressa, de que o imposto sobre os rendimentos de bens reais é um imposto direto. Somos também de parecer que os tributos sobre a renda de cabedais mobiliários entram igualmente na classe dos impostos diretos."

Continuando, acrescenta que, "sendo os encargos taxados nas seções 27 e 37 do ato legislativo de 1894, as quais constituem na sua totalidade a parte do Tariff Act concernente à income tax, verdadeiras fintas diretas, no sentido da constituição, eram inconstitucionais, írritos; e nulos, por não observarem as condições de proporcionalidade, que nela institui”".

Essa resolução foi adotada em sessão plena do tribunal, havendo comparecido então o juiz Jackson, ausente, por moléstia, na assentada de 8 de abril. Não foi, porém, esse magistrado, como se supunha, e corria, quem desempatou contra a lei os votos equilibrados naquela data. Ao contrário, 
Jackson pronunciou-se pela constitucionalidade. Mas o Juiz Shiras, do Estado da Pensilvânia, que na primeira sentença sufragara as disposições do ato de 1894, deixadas por ela em controvérsia, re formou o seu juízo, opinando desta vez com os que fulminaram a nulidade. Solveu, portanto, a dúvida pendente uma simples maioria de cinco contra quatro opiniões, sendo desempatante um voto convertido.

Nem esta circunstância, entretanto, combaliu os créditos da sentença, que foi recebida, no país, "com geral sentimento de desafogo e gratidão".

Sem embargo da leve diferença, por que preponderou a opinião vencedora, a apreciação comum nos Estados Unidos é que este aresto constitui "o mais momentoso acontecimento daquele país, desde a abolição do cativeiro". A lei não era tida propriamente como medida tributária de ordem econômica, mas como um artifício socialista, concebido pelos estados mais pobres, para compelirem os mais prósperos a carregar com injustos gravames. Crê-se que, se prevalecesse, seria o primeiro passo em uma fase de legislação de classes, de caráter cada vez mais socialista. "A sentença do tribunal põe fim a esta ameaça".

Já 73.000 dólares tinham sido arrecadados em execução do ato de 1894, os quais vão ser restituídos pelo tesoiro aos contribuintes. A perda, imediata, que essa decisão inflige ao governo, sobe a 5 milhões de dólares, calculados para as despesas previstas do primeiro semestre, elevando assim o déficit do corrente exercício fiscal a \$50,000,000.

Entre nós, à míngua de outros argumentos para evadir a autoridade jurídica de uma decisão como esta, as relutâncias oficiais buscariam escapatória decisiva no argumento da natureza política do ato impugnado. A este respeito, certos intérpretes nossos ouviram, como se diz, "cantar o galo", mas sem perceber onde. Soou-lhes que, nos casos de caráter político, a competência cessa ante às prerrogativas do Congresso, juiz supremo da apreciação constitucional no tocante às suas atribuições em matérias de administração e governo. A própria jurisprudência dos tribunais tem posto esse limite à sua alçada. Mas a restrição há de entender-se nos seus termos precisos. Não basta que o assunto confine com a política por um ou mais lados. É mister que sejam "exclusivamente" dessa categoria os direitos interessados na espécie. Se, porém, ainda que revestindo por uma ou mais faces esse aspecto, o ato em questão entender com direitos de ordem individual, direitos atinentes à pessoa humana em alguma das suas condições essenciais como a liberdade, a propriedade, ou a vida, os elementos políticos da casa não excluem a soberana competência da magistratura na fixação do pensamento constitucional. Tal a doutrina consagrada ali desde Marshall, reproduzida pela Corte Suprema em vários arestos, como o pronunciado no caso do Estado da Geórgia vs. Stanton, Grant \& Pope (6 Wallace 5078), e desenvolvido na obra capital de Coxe acerca do poder judiciário em matéria de legislação inconstitucional:

The United States Supreme Court is competent to declare a questioned act of Congress to be unconstitutional and void in certain cases; namely those in which the rights in danger are not merelly political rights.

Mas nenhum caso exemplifica tão solenemente como o atual a autoridade dos tribunais em negar execução a atos legislativos de caráter político, logo que atentem contra direitos individuais, assegurados na constituição.

A income tax de 1894 era uma instituição essencialmente política, pela natureza das forças que a produziram, das teorias que a inspiraram, dos fins administrativos a que tinha em mira prover. Política como lei de finanças, política como obra dos fatores socialistas predominantes numa larga seção dos círculos eleitores, que o sufrágio universal entrega às influências da extrema democracia, era a primeira tradução prática do programa de reorganização da sociedade conforme o radicalismo revolucionário que ameaça a civilização moderna.

"Este imposto sobre os ricos, reconhecido pelo governo como imposto sobre os ricos", dizia o advogado Choate, na audiência de 8 do passado, "acaba de ser defendido aqui pelo Attorney General dos Estados Unidos com os princípios mais socialistas e comunistas que jamais se ouviram em qualquer assembléia política". Um correspondente do mais célebre jornal europeu escrevia, pouco depois:

"O socialismo compareceu ante o mais alto tribunal do país, e, em resultado, o povo americano foi posto frente a frente com o fato de que a justiça socialista de 1895 tinha, pelo contrário, entre os funda dores da república e os autores da constituição, os foros de injustiça... A vigorosa linguagem usada no tribunal será lida avidamente e tomada a peito entre os cidadãos de todos os partidos e classes... Podemos contar que esta sentença 
terá por efeito operar uma suspensão no curso das idéias socialistas nos Estados Unidos.

No próprio seio do tribunal os fundamentos, a que se arrimou a minoria dissidente, eram abertamente políticos. O Juiz Harlan, por exemplo, sustentou que a opinião da maioria golpeava as faculdades de defesa do governo contra emergências graves, e constituía um perverso assalto aos direitos do povo. O Juiz Jackson, por sua vez, qualificou-a de calamidade pública. "A maioria do Congresso" diz o Times, "rompera em conflito direto com os princípios da Constituição americana". Desse conflito em que estavam empenhados vastos interesses regionais, violentas aspirações de partido, poderosas maiorias legislativas, formidáveis organizações populares e cálculos importantes da administração financeira, não havia apelo senão para a toga judiciária. Ela, porém, atravessou impassível a fornalha política. E todos esses elementos revoltos, ávidos, intransigentes emudeceram à voz da razão jurídica, enunciada por ela. "Mais uma vez a Suprema Corte dos Estados Unidos lembrou, e de modo notável, aos cidadãos desse país que o Congresso não é onipotente".

É este o vigésimo segundo caso, em que leis do Congresso americano são declaradas inconstitucionais a destarte invalidadas por sentenças daquele tribunal. Os outros vinte e um precedentes, menos o do famoso litígio Dred Scott vs. Standford, acham-se coligidos e estuda dos em um largo apêndice, escrito pelo oficial repórter da Corte Suprema, Mr. Davis, ao volume dos trabalhos daquela corporação dado a prelo no ano da celebração do seu centenário.

Creio que, se nenhum cabedal faz destas coisas os sargentos instrutores do nosso constitucionalismo a Conde de Lippe, o público brasileiro há de ter algum interesse em conhecê-las. Ao menos, convém que ele adquira a consciência da nossa desprezível impostura, quando nos revestimos com as insígnias de um sistema político, de que somos indignos. Eis, pois, em sucinta nomenclatura, as decisões da Suprema Corte americana anulando atos do Congresso Federal:

1 - Questão Hayburn. Ag, 1792. Contra a lei de 23 de março de 1792, que conferia autoridade aos tribunais em matéria de pensões.

2 - United States v. Yale Todd. Fev, 1794. Sentença contra a lei de 23 de março 1792, já aludida, que conferia à justiça poderes não judiciais.
3 - Marbury v. Madison. Fev. 1803. Contra uma disposição da lei de 1789, concernente à organização judiciária, que dava jurisdição originária à Corte Suprema nos casos de "mandamus".

4 - United States v. Ferreira. Dez. 1851. Contra as leis de 3 de março 1823, 26 de junho 1834, e 3 de março 1849, que conferiam aos tribunais de distrito atribuições extrajudiciais.

5 - Dred Scott v. Standford. Contra o ato legislativo que vedava a posse de escravos nos estados setentrionais.

6 - Gordon v. United States. Dez. 1864. Contra as seções 5 e 7 da lei de 3 de março de 1863, sobre apelações.

7 - Ex parte Garland. Dez. 1866. Contra a lei de 24 de jan.1865, concernente ao juramento de solicitadores; e advogados nos tribunais federais.

8 - Hepburn v. Griswold. Dez. 1864. Contra as leis de 25 fev.1862 e 3 de março 1863, relativas ao curso legal do papel moeda.

9 - United States v. De Witt. Dez. 1869. Contra a seção 29, c. 169, da lei de 2 de março 1867, sobre matéria penal, qualificando-a como exorbitante dos poderes atribuídos ao congresso.

10 - The Justice v. Murray. Dez. 1869. Contra a disposição do $§ 5$ c. 80, 12 Stat. 756, acerca do habeas corpus, como contrária à emenda $7^{\mathrm{a}}$ à constituição dos Estados Unidos.

11 - Collector v. Day. Dez. 1870. Contra as leis federais tocantes ao imposto sobre a renda, income tax (13 Stat. 281, 479; 14 Stat. 137, 477), declarando inconstitucionais os ônus impostos aos vencimentos da magistratura dos estados.

12 - United States v. Klein. Dez. 1871. Contra uma cláusula da lei financeira de 12 de julho de 1870.

13 - United States v. Railroad Co. Dez. 1872. Contra a seç. 122 da lei de 1864 sobre rendas internas (Internal Revenue Act), qualificando de inconstitucionais os tributos lançados sobre juros de títulos de caminhos de ferro. 
14 - United States v. Reese. Out. 1875. Contra o prescrito, no tocante a eleições federais, pelos $\$ \S 3$ e 4 da lei de 31 de maio de 1870 , como exorbitante dos limites traçados na $15^{\mathrm{a}}$ emenda à Constituição.

15 - United States v. Fox. Out. 1877. Contra o estatuído nas leis consolidadas (Revised Statutes), $\S_{-} 5^{\circ} 132$, quanto a um ponto de direito criminal relativo a falências, qualificando essa disposição como excessiva da competência do Congresso e invasiva da esfera dos Estados.

16 - Trade Mark Cases. Out. 1879. Contra as seções 4- e 5- da lei de 14 de agosto de 1876, relativas a marcas de fábrica, acoimando de nulidade essas provisões, por se estenderem a um ramo do direito comercial, que não cabe constitucionalmente na jurisdição do Congresso.

17 - Kilbourn v. Thompson, Out. 1880. Contra uma resolução adotada pela Câmara dos Representantes do Congresso dos Estados Unidos, a qual se ingeria em assunto de natureza judicial.

18 - United States v. Harris. Out. 1882. Contra o estatuído, no § 5.519 dos Revised Statutes, por transcender as prerrogativas come tidas pela constituição ao congresso em matéria penal.

19 - Civil Rights Cases. Out. 1883. Contra as seções 1 e 2 da lei de

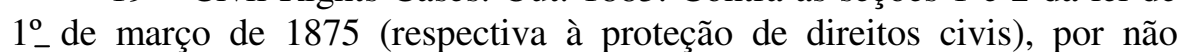
encontrarem apoio nem na emenda $13^{\mathrm{a}}$ nem na $14^{\mathrm{a}}$ do pacto constitucional.

20 - Boyd v. United States. Out. 1885. Contra a seç. 5, c, 391, 18. Stat. 187, concernente à reforma do serviço das alfândegas, como atentatória da $4^{\mathrm{a}}$ e $5^{\mathrm{a}}$ emendas à constituição.

21 - Callan v. Wilson. Out. 1887. Contra o $§ 1.064$ dos Revi sed Statutes, decretados para o distrito de Colúmbia, por ferir o direito ao julgamento pelo júri, transgredindo assim a constituição.

Esses são os casos verificados até 1889, a que têm acrescido outros, nestes seis anos, de alguns dos quais tenho lembrança, mas não farei menção, por não dispor, no momento, de dados precisos. Poderia adicionarlhes, cento e oitenta e três sentenças de inconstitucionalidade e nulidade, proferidas pela Suprema Corte, no seu primeiro século de existência, contra leis estaduais.
Esses fatos ilustram decisivamente o direito americano, hoje brasileiro, que o sábio jurisconsulto Holland, na última edição do seu livro clássico em Inglaterra, como nos Estados Unidos, resume assim:

Uma lei adotada pelo Congresso dos Estados Unidos pode ser inconstitucional; porque o povo soberano submeteu a reservas o Poder Legislativo, conferindo ao Congresso e ao presidente, e confiou à Suprema Corte o encargo de decidir se os atos legislativos se acham, ou não, de conformidade com essas atribuições restritas, cuja delegação reside na legislatura.

O Jornal dos Debates, dando conta, no seu boletim estrangeiro de ontem à tarde, de que a income tax americana "acabara às mãos dessa autoridade judiciária, à qual, nos Estados Unidos, tudo se inclina”, reflete:

"Não é inútil demorarmo-nos um momento ante o espetáculo, que nos oferece a justiça nos Estados Unidos, aniquilando um ato do Congresso. Eis aí uma novidade para os espíritos nutridos na rígida lógica das raças latinas, quanto aos direitos soberanos da representação nacional. Não será mau, talvez, meditar o contraste, que entre si apresentam um povo, cujo ato constitucional estatui que 'o poder judiciário se estenderá a todos os casos, em direito ou equidade, que nascerem desta Constituição e das leis dos Estados Unidos', e outro, que, 'não se supondo menos livre, não deixa aos particulares recurso nenhum contra leis, ou, sequer, contra simples atos do governo, ofensivos dos seus direitos'."

Para a França, porém, era puramente moral a lição, enquanto para nós é rigorosamente legal; porquanto as instituições brasileiras, nesta parte, são de todo o ponto idênticas às dos Estados Unidos. Essa prerrogativa fundamental da justiça americana passou integralmente daquela Constituição, para a Constituição brasileira, com a diferença apenas, em nosso favor de que a atribuição, implícita, segundo a generalidade dos intérpretes desde Marshall, na primeira é expressa, formal e peremptória na segunda.

Que miserável idéia não faz, pois, do nosso regime legal esse elemento faccioso, que imagina revalidar atos inconstitucionais da administração mediante deliberações não menos inconstitucionais do Congresso? Centenas de aprovações parlamentares, imperiosas, cominativas, unânimes não anulariam nunca o mínimo dos direitos 
individuais, ferido por uma inconstitucionalidade. Uma sentença da autoridade judiciária, para a qual é iniludível o apelo, pode mais, neste sistema de governo, do que todas as alianças entre a administração e a legislatura.

Passe e repasse embora a preamar da indulgência política, empenhada em solidar os arbítrios da força. A areia movediça, que uma corrente ajunta, vai-se com a outra. Só a lei constitucional dura, implantada nas profundezas da justiça, como o granito dos recifes no seu engaste submarino.

Querem-se fundar a onipotência real do Executivo, escudada na aparente onipotência do congresso, principiem por abolir virtual mente a Constituição, fechando os tribunais. Mais vale acabá-los do que desonrálos, convertendo-os em rabadilha do poder irresponsável. Se as armas não se inclinarem à justiça, ao menos que a justiça não seja a cortesã das armas. Estas não precisam dela, e, dispensando-lhes os serviços, poupariam, ao menos, a última das degradações morais a um povo resignado ao aniquilamento. 